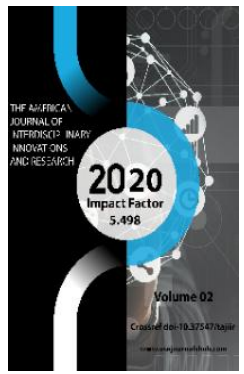

\title{
Examples Of Folklore In The Textbook "O‘Qish Kitobi" Of Uzbek Primary Schools
}

\author{
Abdurakhmonava Dinora Yusupovna \\ Lecturer Of Primary Education Methodology, Jizzakh State Pedagogical Institute, Uzbekistan
}

Journal Website:

http://usajournalshub.c

om/index,php/tajiir

Copyright: Original content from this work may be used under the terms of the creative commons attributes 4.0 licence.

\section{ABSTRACT}

The younger generation is the foundation of our future. Thus we need to pay more attention to primary education. The main part of the important task of educating primary school students is carried out in reading classes. The textbooks also cover a wide range of folklore that students love to read. Folklore includes fairy tales, epics, legends, narrations, songs, folk songs, riddles, parables, anecdotes and stories. Folklore has long been a source of education.

\section{KEYWORDS}

Reading lesson, reading textbook, folklore, fairy tale, epic, narration, riddle and parable.

\section{INTRODUCTION}

The physical and spiritual development and intellectual potential of the younger generation play an important role in the development of society, the destiny of the country and the nation. As the head of our state Shavkat Mirziyoyev noted, "Today, as the world is changing rapidly and various new threats and dangers that threaten the stability and sustainable development of peoples are emerging, it is more important than ever to focus on the spirituality and enlightenment, moral education, youth education and the pursuit of perfection."

A number of important documentson improving the state youth policy identified in the Action Strategy for the five main initiatives of development of the Republic of 
Uzbekistan, protection of the rights and interests of young people and on creating the necessary conditions for their harmonious developmenthave been adopted, practical work has been done, certain results have been achieved. However, the work to be done in this area is always extensive and relevant. In this regard, under the leadership of the President, on March 19, 2019, in the video conference "On theimplementation of the 5 main initiatives in the effective organization of work with youthon increasing interest to read a book, to culture, art, sports and information technology", issues related to youth development were discussed and 5 main initiatives in this area were put forward. These are followings:

The first initiativeserves to increase the interest and highlight the talent of young people in music, painting, literature, theater and other arts.

Thesecondinitiativeis aimed at creating the necessary conditions for young people to be fit and show their abilities in sports.

The third initiativeis aimed at promoting the effective use of computer technology and the Internet among the population and youth.

The fourthinitiativeis aimed at increasing the spirituality of young people and organizing the systematic work to promote reading among them.

The fifth initiativeimplies the issues regarding the employment of women.

According to the fourth initiative,creating a love for books from an early age in young people, the formation of critical thinking and a broad outlook are a solid foundation in their lives.

The school is an educational institution, and the future of the individual depends on how it is implemented in the institution, and how the teacher, being an educator, reacts to his duties and responsibilities. This is the basis for educating a harmoniously developed person, first of all, as a selfless person for the society and for the people among he lives.

It is well known that the main part of the important task of educating primary school students is carried out in reading lessons. The primary school textbook "O'qishkitobi" is based on the concept of "Reading and speech development" program, which meets the requirements of state educational standards. It takes into account the thematic, aesthetic, partly seasonal systems. It, in turn, involves the child's perception of his surroundings.

The textbooks also cover a wide range of folklore that students love to read. Oral literature created by the people is called folklore. Longman Advanced Learners' Dictionary defines "Folklore" is originally an English word; "Folk" is people, "Lore" is knowledge or information about a subject, for example nature or magic, that is not written down but is passed from person to person. Together they mean "folk wisdom".

Uzbek folklore, consisting of various genres, is an art of expression that reflects the worldview, dreams and aspirations of the Uzbek people. Folklore includes fairy tales, epics, legends, narrations, songs, lapars, riddles, parables, anecdotes and stories.

Primary school curricula place a complex challenge on reading lessons, such as helping 
students develop good reading skills. The materials of folklore play an important role in the implementation of such tasks. Primary school students are naturally fond of proverbs, riddles, and fairy tales, and read them with great interest. In addition, folklore has long been a source of education.

Primary school students are first introduced to fairy tales. It is well known that fairy tales are one of the oldest and most popular genres of folklore. The term "ertak"(fairy tale) appears in Mahmud Kashgari's 11thcentury work "Devonu lug'atit turk" as "etuk" and means to narrate an event orally. There are also other names of ertak (fairy tales) called matal, ushuk, varsaqi, cho'pchak in various areas of Uzbekistan. Fairy tales are an epic type of folklore. Its distinctive feature is the busyness of the story, the ability to tell a story in a perfect way. Fairy tales reflect the realities of life in a wonderful, strange and attractive way.

A fairy tale is a folklore work. That is why fairy tales are a product of oral tradition and are told in many ways, spread by word of mouth. They are traditional, have unknown creator, and a plot is told in several variants among the people. The artistic form and poetics of fairy tales are unique. Fantastic fiction is associated with the realities of life and reflects the ancient concepts, customs and rituals themselves.

One of the hallmarks of a fairy tale is that the events and happenings are interpreted by the narrator and the listener not as "real events" but as "unrealones". Therefore, in fairy tales, the place and time of events are described in an ambiguous general way. In addition, the role of fairy tales in terms of time and place varies. It is obvious that fairy tales differ from other genres of folklore in their peculiarities.

One travels to the world of fairy tales as a child, first hearing fairy tales about animals. They get acquainted with the world of intelligent and stupid, generous and jealous, cruel and just people of all kinds. The fairy tales describe the life of the people, their hopes for justice and truth, their anger against the forces of evil, and their love for the good. After reading fairy tales, children tell them to their friends, brothers and sisters, and most importantly, they try to emulate the positive heroes they love, and to be like them in honesty, truthfulness, and hard work. He hates negative heroes and tries to be different.

This means that the use of fairy tales has a positive effect on both increasing readers' interest in knowledge and educating them to become perfect human beings.

In the primary grades, students are introduced to many examples of folklore through textbooks. There is a set amount of time in the primary school curriculum to study these works.

Textbooks from 1st grade to 4th grade have folklore as a separate section and set specific hours for their study.

In particular, 9 hours are allocated in the curriculum for the study of the section "Xalqo'giti - baxtkaliti" in the textbook "Reading book" for 1st grade.

The section "Xalqo'giti - baxtkaliti" includes examples of oral creations that have entered the hearts of children through the lullaby, creating an idea of goodness, correctness, 
honesty, delicacy, friendship, camaraderie and harmony. The works that students should read in class and independently:

1. The Tale about"the Lion and the Mouse".

2. The Tale about"the Monkey and the Carpenter".

3. The Tale about "the Honest Child".

4. The song "The stork has come summer is here"(Laylakkeldi yozbo'ldi).

5. Anecdotes.

6. Proverbs

7. Riddles

15 hours are devoted to the study of the section "Fairy tales - a guide to goodness" (Ertaklar -yaxshilikkayetaklar) in the textbook "Reading" for 2nd grade. Through this section, students travel to the world of fairy tales. They learn what is good and what is bad through fairy tales. Particular attention is paid to the narration of the heroes of fairy tales, the depiction of events in pictures.

The fairy tales that students should read in class and independently:

1. Uzbek fairy tales such as "Tansihatliktumanboylik", "Kenjao'g'il”, "Engyaxshisovg“a”, “Aqlli bola”, "Hakka bilantulki”; "Somoncho'g“valoviya" "Aka-uka Grimm ertaklari", an Iranian fairy tale "Tulkivaxo'roz", “ Qarg'abilantulki”, "Mushukvasichqon" are children's favourite ones.

17 hours are devoted to the study of the section "Folklore" in the textbook "Reading" for 3 rd grade. This section includes songs, fairy tales, proverbs, anecdotes, and riddles about folklore. Through them, students are taught the idea of friendship, harmony, patriotism, diligence, honesty, glorification of virtues, condemnation of negative qualities. Students get acquainted with the song. They read Uzbek folk tales such as "Halollik", "Donishmandyigit" and Kyrgyz folk tales "Ahillik-ulug'baxt". They also study the story "Qushini". They read proverbs, sayings, anecdotes, riddles, and tongue twisters as well.

29 hours are allocated for studying the section "Folklore" in the textbook "Reading" for 4th grade. Children learn about the magic and fantasy tales created by our people for thousands of years, songs expressing the pain, desire and dream of the people, children's merry songs, riddles that require answers, ingenuity, wise sayings in the form of people's life conclusions. Theyalso read fascinating narrations. The section itself consists of 5 parts:

Part 1 is called "On the Wings of Songs" (Qo'shiqlarqanotida). It includes the songs "Boychechak", "Oftobchiqdiolamga", "Xo'phayda".

Part 2 is called "In the Land of Fairy Tales" (Ertaklarmamlakatida). It includes such tales as "Davlat”, “Ilmafzal”, "Ko'zachabilantulki”, “Ochko'z boy”, "Hiylagarningjazosi”, “Ziyrakuchyigit”, ”Hunarsizkishio'limgayaqin”.

Part 3 is called "Literary Tales" (Adabiyertaklar), which includes Anvar Abidjan's

"Bo'riningtabibbo'Iganihaqidaertak", ShukurSadulla's "Laqma it", A. Abdurazzaq's "Baqabilantaqa".

Part 4 is called"Proverbs" (Maqollar), which contains 17 proverbs. 
Part 5 is called"Riddles" (Topishmoqlar). Here are 5 riddles.

An analysis of the content of folklore in the primary school textbooks shows that from the time children enter school they enjoy the immortal heritage of the people, the source of spirituality, that is, the examples of oral art. In the process of studying these works, it is the most responsible task of every teacher to pay attention to their educational aspects and to use them effectively in the formation of human qualities of the younger generation.

The following objectives are set for the study of fairy tales in primary school:

1. To bring up children in the spirit of harmoniously developed people, to bring up in them the feeling of love for the Motherland and society.

2. To educate students on the materials of folk tales on the basis of state educational standards.

3. To encourage students to read fairy tales.

4. To develop students' reading and speaking skills.

The main educational task in reading fairy tales is to form children in the spirit of harmoniously developed person. Therefore, special attention through the reading of fairy tales in primary school should be paid to the general development of students, the formation of values of patriotism, friendship, self-management in community, diligence, honesty, truthfulness, a conscious attitude to reading.

\section{REFERENCES}

1. Jo'rayev M., EshonqulovE ,. Folklorshunoslikkakirish (Textbook).- T.: "Barkamolfayz media", 2017

2. Gafforova T., Shodmonov E., "O'qishkitobi" 1st grade. Tashkent: "Sharq" Publishing and Printing JointStock Company, 2018.

3. T.Gafforova, Sh. Nurullayeva, Z. Murzahakimova "O'qishkitobi" 2nd grade. Tashkent: "Sharq" Publishing and Printing Joint-Stock Company, 2018.

4. M. Umarova, Kh. Khamrakulova, R. Tadjibayeva "O'qishkitobi" 3rd grade Tashkent: "O'qituvchi”, 2019

5. Matchonov.S, Sojalilov.A“O'qishkitobi" 4th grade. Tashkent.: "Yangiyo'Ipoligrafservis", 2017.

6. Jabborov Sh. Xalq og'zaki ijodidan foydalanish// Boshlang'ichta'lim, 2011, issue 2, pp 28-29.

7. Jumaboyev $M$. Bolalar adabiyoti va folklor.- Tashkent: Publishing House of the Literary Fund of the Writers' Union of Uzbekistan, 2006.

8. Muhamadjonovna, S. D. (2020). The development of sociolinguistic competence of future English language teachers through computer technologies. European Journal of Research and Reflection in Educational Sciences, 8 (3) Part II, 147-150.

9. Sarimsakova, D. M. (2020). SOCIOLINGUISTIC COMPETENCE AND COMMON REFERENCE LEVELS OF THE CEFR. In МИРОВАЯ ЭКОНОМИКА. ПРОБЛЕМЫ, ПЕРСПЕКТИВЫ, ИННОВАЦИИ (рp. 4-6).

10. Toshpulatova, D. (2019). РОЛЬ МЕНТАЛЬНОЙ АРИФМЕТИКИ В 
ПОВЫШЕНИИ МАТЕМАТИЧЕСКОЙ

ГРАМОТНОСТИ В НАЧАЛЬНОЙ ШКОЛЕ.

Theoretical \& Applied Science, (12), 184-

186. 